\title{
O PODER DE NEGOCIAÇÃO PROCESSUAL DO MINISTÉRIO PÚBLICO EM MATÉRIA RECURSAL ${ }^{1}$
}

\section{THE POWER OF PROCEDURAL AGREEMENTS CONDUCTED FOR PUBLIC PROSECUTOR'S OFFICE IN RECURSAL MATTERS}

Tânia d'Able Rocha de Torres Bandeira Pós-graduada em Direito Processual Civil pela Escola Superior de Magistratura de Pernambuco. Pós-graduada em Direito Processual Civil e Tutelas Coletivas e Instrumentos de Defesa da Cidadania pela Faculdade de Direito da Fundação Escola Superior do Ministério Público. Promotora de Justiça do Ministério Público do Estado de Goiás. Titular da $5^{\text {a }}$ Promotoria de Justiça de Águas Lindas de Goiás/GO. Email: taniadable@gmail.com

RESUMO: O presente trabalho versa sobre a legitimidade do Ministério Público para realizar negócios processuais nas causas em que atue, seja como parte ou como custos juris, especialmente em matéria recursal, analisando se, no contexto do neoprocessualismo, o interesse público tutelado pelo Parquet o impediria ou não de firmar acordos de instância única ou desistência de recurso.

PALAVRAS-CHAVE: Negócios processuais; Ministério Público; Custos juris; Convenção em matéria recursal; Art. 190 do Código de Processo Civil.

ABSTRACT: This paper aims to treat about the legitimacy of the Public Prosecutor's Office to conduct procedural agreements in the cases in which it acts, both as part or as custos juris, especially in recursal matters, analyzing if, in the context of neoprocessalism,

\footnotetext{
${ }^{1}$ Artigo recebido em 10/12/2018 e aprovado em12/07/2019.
} 
the public interest protected by Public Prosecutor's Office would prevent it or not to sign deals of single instance or withdrawal of appeal.

KEY WORDS: Procedural agreements; Public Prosecutor's Office; Custos juris; Convention on appeal; Art. 190 of the Brazilian Code of Civil Procedure.

\section{Introdução}

Com o advento do novo Código de Processo Civil que instituiu um verdadeiro sistema de Justiça Multiportas, cujo foco não é mais a mera finalização do processo em si, mas a solução adequada da controvérsia, vislumbrou-se a necessidade de se estudar a amplitude do dispositivo que trata da negociação processual, a fim de se alcançar o verdadeiro intuito teleológico da norma.

Como o Ministério Público possui atuação sui generis no processo, ora atuando como parte e outras vezes como custos juris, sendo uma instituição consagrada como essencial à atividade jurisdicional, é imprescindível analisar se os membros do Parquet podem firmar convenções processuais, visto que sempre atuam na tutela do interesse público primário.

Diante disso, o presente trabalho tem por objetivo realizar uma análise acerca da amplitude das convenções processuais e sua forma de utilização pelo Ministério Público, visto que a atuação deste órgão somente se legitima quando tem por objetivo a tutela do ordenamento jurídico, do regime democrático e dos direitos e garantias fundamentais instituídos na Constituição Federal.

\section{Negócios processuais no novo Código de Processo Civil}

\subsection{Generalidades}

O novo Código de Processo Civil, introduzido pela Lei $\mathrm{n}^{\circ}$ 13.105/2015, trouxe, como uma de suas inovações, a ampliação da possibilidade de se realizar atos de negócios 
processuais. Essa sistemática permitiu que as partes possam atuar mais ativamente no processo, alterando a antiga visão que se tinha de uma pirâmide, em que o juiz ficava no cume, promovendo o andamento do processo e as partes colocavam-se quase que como meros expectadores.

Com a reforma, houve uma total mudança de paradigmas: as partes passam a atuar ao lado do juiz, como verdadeiros parceiros na condução do processo. Justamente por isso, o Código de Processo Civil de 2015, em diversos de seus dispositivos ressaltou o dever de as partes de cooperar com o processo, bem como concedeu mais amplitude ao princípio da boa-fé processual, podendo-se visualizar isso em seus artigos $5^{\circ}$ e $6^{\circ}$.

Esse novo modelo tem sido denominado modelo cooperativo de processo, no qual não há supremacia de sujeitos, conforme pondera Simone Furlan ${ }^{2}$, competindo ao magistrado participar, contribuindo para o diálogo entre as partes para que se chegue à melhor solução da controvérsia.

Consoante ressalta Elpídio Donizetti, o modelo constitucional de processo não se satisfaz em simplesmente concretizar a vontade da lei, o provimento jurisdicional deve ser construído com a efetiva participação dos litigantes, devendo haver igualdade e paridade entre eles ${ }^{3}$.

Baseado nesta dinâmica de que as partes possuem o dever de cooperar com o processo e de atuar juntas, ativamente, para a construção do provimento jurisdicional, o legislador introduziu os artigos 190 e 357, §2 no Código de Processo Civil que consagram a negociação processual e o saneamento consensual do processo, respectivamente.

O primeiro dispositivo citado permite às partes firmar acordos sobre ônus processual, poderes, deveres, provas, prazos e até mesmo alterar o rito do processo. O art. 191, por sua vez, preconiza a possibilidade de ser fixado um calendário processual pelas partes que, caso haja anuência do magistrado, vinculará a todos. É o que se denomina contratualismo

\footnotetext{
${ }^{2}$ FURLAN, Simone. A audiência de saneamento compartilhado do art. 357 , § $3^{\circ}$, do cpc/2015 e os princípios da cooperação e efetividade. Revista Eletrônica de Direito Processual - REDP, Rio de Janeiro: 2017, Ano 11, volume 18, número 3, set./dez. 2017, p. 361. Disponível em: https://www.epublicacoes.uerj.br/index.php/redp/article/view/31700. Acesso em: 04 de fevereiro de 2018.

${ }^{3}$ DONIZETE, Elpídio. Novo código de processo civil comentado (Lei no 13.105, de 16 de março de 2015): análise comparativa entre o novo CPC e o CPC/73. São Paulo: Atlas, 2015, p. 1.
} 
processual, em que as partes, por meio de um acordo, fixam normas referentes ao curso do processo, com o intuito de obter maior adequação do processo para o alcance da solução do litígio, conforme discorre Elpídio Donizete ${ }^{4}$.

Deve-se ressaltar que os negócios processuais produzem efeitos no exercício da jurisdição e, como esta é uma função pública, obviamente a contratualização do processo é regulada e possui objeto restrito, devendo-se respeitar as garantias constitucionalmente asseguradas, a fim de se resguardar, especialmente, o princípio do devido processo legal.

O neoprocessualismo é justamente a visão atual de que o processo civil é um instrumento para a garantia dos direitos preconizados na Constituição, sempre levando em consideração a força normativa da Carta Magna. Diante disso, o direito processual não pode se afastar dos direitos e garantias fundamentais constitucionais, razão pela qual os atos negociais processuais são decorrência do próprio direito à liberdade previsto na Constituição Federal, que consagra o autoregramento da vontade no processo, conforme leciona Fredie Didier Júnior, que explicita o papel do direito processual moderno que não estar dissociado do autoregramento da vontade, discorrendo que "um processo que limite injustificadamente o exercício da liberdade não pode ser considerado um processo devido" 5 .

Embora o novo Código de Processo Civil tenha instituído um regime jurídico de disponibilidade, baseado no princípio da liberdade negocial, conforme bem esclarecem Wambier e Talamini ${ }^{6}$ subsistem em nosso ordenamento normas processuais que são inderrogáveis e inafastáveis pela vontade das partes, as denominadas normas cogentes. Isso por duas razões: preliminarmente, é consabido que o direito à liberdade não é ilimitado, devendo respeitar as demais garantias constitucionais; em segundo lugar porque reflete no exercício da jurisdição que é função pública. Assim, tem-se como exemplos de normas cogentes que restringem o poder convencional das partes: a disposição referente ao

\footnotetext{
${ }^{4}$ DONIZETE, Elpídio. Curso didático de direito processual civil. São Paulo: Atlas, 2017, 20. Ed, 384.

${ }^{5}$ DIDIER JR., Fredie. Princípio do respeito ao autorregramento da vontade no Processo Civil. In: CABRAL, Antonio; NOGUEIRA, Pedro Henrique Pedrosa (Coords.). Negócios processuais. Salvador: Juspodivm, 2015, v.1, p. 19-21.

${ }^{6}$ WAMBIER, Luiz Rodrigues. TALAMINI, Eduardo. Curso avançado de processo civil: teoria geral do processo. São Paulo: Revista dos Tribunais, 2016, 16. ed., v.1, p. 48-49.
} 
reexame necessário e a coisa julgada, visto que foram instituídas no próprio interesse da atividade jurisdicional do Estado. Sem a previsão da coisa julgada, por exemplo, seria imposto ao Judiciário reanalisar qualquer matéria posta em Juízo, o que sobrecarregaria a máquina pública e contribuiria ainda mais para ineficiência da justiça, acarretando uma violação ainda maior às garantias constitucionais do cidadão.

Assim, a possibilidade de serem negociadas as normas processuais é decorrência do direito à liberdade preconizado na Constituição Federal. A plasticidade do procedimento, portanto, baseia-se, em regra, na possibilidade de as partes realizarem autocomposiçao como forma de solução do conflito, razão pela qual podem adequar o procedimento às suas necessidades, permitindo-se que sejam firmados negócios processuais ainda que atípicos, conforme autoriza o art. 190 do Código de Processo Civil.

\subsection{Espécies de negócios processuais e seus requisitos}

A doutrina classifica os negócios processuais em típicos e atípicos, denominando de típicos, aqueles que estão expressamente descritos na legislação. O Código de Processo Civil de 1973 já admitia negócios processuais típicos, tal como a possibilidade de as partes firmarem convenção acerca da cláusula de eleição de foro, acordo de suspensão do processo ou quanto à renúncia ao oferecimento de recurso.

É bem verdade que uma pequena parte da doutrina entendia que o art. 158 do antigo Código de Processo Civil concedia permissão para uma certa elasticidade na realização de negócios processuais, contudo a maior parcela dos juristas adotava a posição de que as consequências jurídicas desses negócios processuais típicos eram efeitos automáticos da lei, não decorrendo diretamente da vontade das partes e que, por isso, caracterizavam-se como fatos jurídicos e não como verdadeiros negócios jurídicos. ${ }^{7}$

O Código de Processo Civil de 2015, embora contenha previsão de negócios processuais típicos, semelhantes ao antigo Código, tal como desistência de recurso (art. 998), renúncia a recurso (art. 999), negócio tácito que permite o trâmite processual em juízo relativamente incompetente (art. 65), introduziu novas espécies de negócios 
processuais típicos, bem como inseriu uma cláusula geral que concede autonomia às partes para firmar negócios processuais atípicos.

Entre os negócios típicos inseridos no CPC/2015 têm-se, por exemplo, o adiamento negociado da audiência sem limitação (art. $362, \mathrm{I})^{8}$, saneamento consensual do processo $\left(357, \S 2^{\circ}\right)$, convenção sobre o ônus da prova $\left(373, \S \S 3^{\circ}\right.$ e $\left.4^{\circ}\right)$, escolha consensual do perito (art. 471), calendarização processual (art. 191), dentre outros. ${ }^{9}$

Embora existam opiniões céticas a respeito de amplitude de utilização de atos negociais pelas partes, a exemplo de Misael Montenegro Filho ${ }^{10}$ que afirma desacreditar que o saneamento consensual do processo venha a ocorrer com frequência, uma vez que o direito brasileiro está habituado ao litígio, é inegável a evolução propiciada pelo novo Código de Processo Civil rumo à solução democrática do processo.

O art. 190 do atual Código de Processo Civil trouxe uma cláusula geral permissiva da convenção negocial atípica, possibilitando que sejam introduzidas, por meio de acordo de vontades, alterações no procedimento para ajustá-lo às especificidades da causa, sem restringir quais modificações seriam estas. Isso significa que se concedeu uma grande liberdade às partes, dando-se primazia ao princípio da autonomia da vontade, mais comumente utilizado no Direito Civil, que nada mais é do que uma das expressões do direito constitucional à liberdade, consagrando o princípio do neoprocessualismo, conforme já mencionado no tópico 2.1 deste trabalho.

O citado dispositivo prevê os seguintes requisitos para se admitir a negociação processual: partes capazes, equilíbrio entre as partes (sem o qual o juiz poderá declarar inválido o acordo) e que a causa verse sobre direitos que admitam autocomposição.

8 O CPC/73 dispunha de forma semelhante no art. 453, I, mas limitava o adiamento de audiência a uma única vez.

9 Conferir CUNHA. Leonardo Carneiro da. Negócios jurídicos processuais no processo civil brasileiro. In: CABRAL, Antonio do Passo; NOGUEIRA, Pedro Henrique. (Coords.). Negócios processuais. Salvador: Juspodivm, 2015, v.1, p. 50-51.

${ }^{10}$ MONTENEGRO FILHO. Misael. Novo código de processo: modificações substanciais. São Paulo: Atlas, 2015, p. 60. 
Sobre esse ponto, interessante é a crítica feita por Mirna Cianci e Bruno Lopes Megna $^{11}$ acerca da exigência de que se trate de direito que admita autocomposição, pois a redação do dispositivo deixa transparecer que o direito material em litígio é relevante para a análise do ato negocial, quando, na verdade, a convenção processual em si não abrange o mérito da causa ou o direito material, que é objeto do instituto da transação. A convenção processual cuida, tão somente, de matéria processual. Diante disso, surgem duas interpretações: a primeira restritiva, na qual se exige que a possibilidade de autocomposição do direito material e processual posto em juízo; e a segunda ampliativa, na qual se aplica uma interpretação teleológica para se permitir acordos processuais em qualquer situação, estando sua validade condicionada à ausência de nulidade, ao respeito ao direito constitucional ao processo justo e demais requisitos que regem qualquer negócio jurídico.

Quanto à interpretação mais restritiva, na qual se entende ser somente possível o negócio processual quando o direito material admita autocomposição, Wambier e Talamini $^{12}$ esclarecem que não são apenas os direitos materiais disponíveis que admitem autocomposição. Nosso ordenamento jurídico não deixa dúvidas de que a autocomposição é possível em tutela de direitos indisponíveis ou transindividuais. Basta lembrar que os direitos difusos e coletivos admitem a realização de termo de ajustamento de conduta, que nada mais é do que uma forma de autocomposição do conflito.

Diante disso, indaga-se: por que não seria possível a realização de negócios processuais em ações para a tutela de direitos difusos, coletivos e outros direitos materiais indisponíveis? Poderia o Ministério Público realizar negócios processuais nos processos em que atue? Esses pontos são o objeto primordial de estudo deste trabalho que serão melhor explicitados adiante.

\section{Negociação em direitos indisponíveis}

4.

\footnotetext{
${ }^{11}$ CIANCI, Mirna; MEGNA, Bruno Lopes. Fazenda Pública e Negócios Jurídicos Processuais no novo CPC: Pontos de partida para o estudo. In: CABRAL, Antonio; NOGUEIRA, Pedro Henrique Pedrosa (Coords.). Negócios processuais. Salvador: Juspodivm, 2015, v.1, 2015, 488-490).

${ }^{12}$ WAMBIER, Luiz Rodrigues. TALAMINI, Eduardo. Op. Cit, p. 516.
} 
Para o bom desenvolvimento do presente estudo, é imprescindível abordar de forma mais aprofundada se as causas que versam sobre direitos indisponíveis admitem negociação, seja material ou processual.

Um tema que possui correlação com este tópico é a análise que se faz acerca de ser ou não possível autocomposição sobre os direitos da Fazenda Pública. A indisponibilidade do interesse público que deve sempre ser tutelado pela Administração Pública acarreta, necessariamente, a impossibilidade de autocomposição desses direitos?

Inicialmente, deve-se destacar que a supremacia do interesse público nem sempre terá como consequência uma incongruência com o interesse privado. Existem situações em que o interesse particular é coincidente com o interesse público como, por exemplo, quando a Administração firma um contrato com o particular. Por outro lado, a indisponibilidade do interesse público nem sempre acarretará a indisponibilidade de todos os direitos da Administração. Os direitos da Administração não serão necessariamente direitos indisponíveis, admitindo-se a transação e a solução consensual de conflitos. Indisponibilidade não significa intransigibilidade ${ }^{13}$.

A legislação até então vigente já demonstrava a possibilidade de a Fazenda Pública realizar transação (art. 10 da Lei $\mathrm{n}^{\circ} 10.259 / 01$ e art. $8^{\circ}$ da Lei $\mathrm{n}^{\circ} 12.153 / 09$ ) e agora com a atual redação do art. 174 do Código de Processo Civil ficou clara a possibilidade de a Administração Pública realizar solução consensual de conflitos. É possível perceber que a solução consensual de conflitos vem sendo incrementada em diversos ramos do Direito Público, tal como a transação penal, a suspensão condicional do processo (no Direito Penal) e o acordo de leniência (no Direito Administrativo).

Sobre os atos convencionais em matéria de processo civil, Leonardo Carneiro da Cunha $^{14}$ esclarece ser possível, por exemplo, a celebração de negócio jurídico processual para fixar outras formas de intimação pessoal da Fazenda Pública, citando, inclusive, o enunciado 30 do II Fórum Nacional do Poder Público - Vitória/ES: "É cabível a celebração de negócio jurídico processual pela Fazenda Pública que disponha sobre formas de intimação pessoal”.

\footnotetext{
${ }^{13}$ CIANCI, Mirna; MEGNA, Bruno Lopes. Op. Cit., p. 491-492.

${ }^{14}$ CUNHA. Leonardo Carneiro da. A Fazenda Pública em juízo. Rio de Janeiro: Forense, 2017, 14. ed, p. 58. 
Ora, se a convenção processual for utilizada de forma impessoal, legal, moral, transparente para se alcançar o interesse público de maneira mais eficaz, não se vislumbra qualquer impossibilidade em sua utilização pela Fazenda Pública. Primando-se o princípio da eficiência e da razoável duração do processual não há razão para se impedir a realização de negócios processuais para a tutela do interesse público. Assim, a indisponibilidade do interesse público não acarreta impedimento à celebração de negócio processual pela Fazenda Pública.

Neste sentido, o citado doutrinador ressalta que o Fórum Permanente de Processualistas Civis elaborou os enunciados de $n^{\circ} 135$ e 256 que dispõem, respectivamente, o seguinte: "A indisponibilidade do direito material não impede, por si só, a celebração de negócio jurídico processual” e, que "A Fazenda Pública pode celebrar negócio jurídico processual" ${ }^{\prime 15}$.

Merece destaque também a ponderação feita por Raphael Noleto Auad de Gomes ${ }^{16}$ no sentido de que, embora seja possível a celebração de negócios processuais pela Fazenda Pública, sua utilização possui limites mais contundentes que as convenções realizadas por particulares, face ao regime jurídico-administrativo próprio que rege as atividades estatais, devendo ser verificado na hipótese concreta se foram respeitados os postulados da supremacia e da indisponibilidade do interesse público.

Pela mesma razão, não se vislumbra óbice à possibilidade de o Ministério Público firmar negócios processuais, desde que a finalidade seja sempre a tutela do interesse público, mantendo-se as mesmas observações feitas em relação à Fazenda Pública, devendo a atuação ser impessoal, pautada na legalidade, moralidade, transparência, com o intuito de se obter eficiência e a razoável duração do processo.

É pertinente mencionar que alguns diplomas normativos demonstram que a indisponibilidade dos direitos difusos e coletivos não impede a realização de transação, tal

\footnotetext{
${ }^{15}$ Ibidem, p. 668.

${ }^{16}$ GOMES, Raphael Noleto Auad de. Da (in)aplicabilidade da cláusula geral de negociação processual no âmbito da fazenda pública em juízo. Revista de Direito da Procuradoria-Geral do Estado de Goiás RPGEGO, Belo Horizonte, ano 29, n. 31, jan/dez., 2016, p. 19. Disponível em: <http://www.bidforum.com.br/bidBiblioteca_pre_periodico_ap.aspx?tp=1\&p=1550\&abrev=REV>. Acesso em: fevereiro de 2018.
} 
como o art. $5^{\circ}, \S 6^{\circ}$ da Lei $n^{\circ} 7.347 / 85$ e art. 79-A da Lei 9.605/98. Ora, se o ordenamento jurídico brasileiro admite transação em matéria de direitos indisponíveis (que atua diretamente sobre o direito material), maior ainda a razão para se entender que inexiste óbice à realização de convenção processual. Conclui-se, portanto, que a indisponibilidade do direito material não implica necessariamente a indisponibilidade do direito processual ${ }^{17}$.

Interessante artigo de autoria de Daniela dos Santos Bomfim e Fredie Didier Júnior ${ }^{18}$ defende a possibilidade de se realizar, inclusive, autocomposição de direito material em matéria de Improbidade Administrativa ${ }^{19}$, sob o argumento de que a Lei de Improbidade Administrativa foi instituída em data anterior à introdução de técnicas de composição no direito penal, a exemplo da transação penal e da suspensão condicional do processo, inseridas pela Lei 9.099/95. Argumentam que, se na seara penal, que é o âmbito do direito que impõe maior gravame ao cidadão, passou-se a admitir negociação, maior razão para se permitir negociação nas sanções cíveis de improbidade. Os referidos autores, ao desenvolverem o trabalho acerca do negócio atípico de colaboração premiada, abordam a aplicação analógica dos efeitos materiais dos acordos típicos de colaboração premiada, fazendo um comparativo com a possibilidade de se utilizar autocomposição em matérias de improbidade administrativa. Defendem que a Lei Anticorrupção (Lei n 12.846/2013) compõe com a Lei de Improbidade Administrativa um microssistema de combate a atos lesivos à Administração Pública, sustentando que o $\S 1^{\circ}$ do art. 17 da Lei $\mathrm{n}^{\circ} 8.429 / 92$ teria sido tacitamente revogado pelo art. 36, ( $^{\circ}$, da Lei n ${ }^{\circ}$ 13.140/2015 (Lei da Mediação) que, expressamente, admite autocomposição em ação de improbidade administrativa.

\footnotetext{
${ }^{17}$ MAZZEI, Rodrigo; CHAGAS, Barbara Seccato Ruis. Os negócios jurídicos processuais e a arbitragem. In: CABRAL, Antonio; NOGUEIRA, Pedro Henrique Pedrosa (Coords.). Negócios processuais. Salvador: Juspodivm, 2015, v.1, p. 528.

18 DIDIER JR., Fredie. BOMFIM, Daniela Santos. A colaboração premiada como negócio jurídico processual atípico nas demandas de improbidade administrativa $A \& C$. Revista de Direito Administrativo \& Constitucional, Belo Horizonte, ano 17, n. 67, jan./mar. 2017, p. p. 116-118. Disponível em <https://www.academia.edu/32483221/A_colabora\%C3\%A7\%C3\%A3o_premiada_como_neg\%C3\%B3cio_ processual_at\%C3\%ADpico_no_processo_da_improbidade_administrativa>. Acesso em: janeiro de 2018. DOI: $10.21056 /$ aec.v17i67.475.

${ }^{19}$ Ressalte-se que a Resolução 179/2017 do CNMP admite, em seu art. $1^{\circ}, \S 1^{\circ}$ e $\S 2^{\circ}$, negócios processuais em matéria de improbidade administrativa ao tratar do termo de ajustamento de conduta, desde que haja o devido ressarcimento ao erário e a aplicação de uma das sanções previstas na Lei 8.429/92.
} 
Em suas conclusões afirmam ser admissível a colaboração premiada e o acordo de leniência como negócios jurídicos atípicos no processo de improbidade administrativa (art. 190 do CPC c/c o art. $4^{\circ}$ da Lei $n^{\circ} 12.850 / 2013$ e com os arts. 16-17 da Lei $n^{\circ}$ 12.846/2013), bem como a negociação dos processos de improbidade administrativa na respectiva ação penal, quando isso for possível, podendo o acordo ser parcial que passará a ser considerado a parcela incontroversa do litígio.

Posto isso, uma vez esclarecido que não há impedimento para se realizar negociação processual ainda que se trate de direitos indisponíveis, deve-se aprofundar o estudo da utilização de negociação por parte do Ministério Público.

\section{Capacidade negocial do Ministério Público - como parte e como custos juris}

Inicialmente, convém tratar da capacidade negocial do Ministério Público em geral, ou seja, tanto em relação ao direito material quanto em relação ao direito processual. Como se sabe, o Ministério Público atua na tutela dos direitos difusos, coletivos e individuais homogêneos, sempre voltado à sua finalidade institucional, promovendo a defesa da ordem jurídica e do regime democrático (art. 127 da Constituição Federal). A forma de atuação do Parquet para a defesa desses direitos pode ocorrer como parte, ou como fiscal da ordem jurídica, nos processos que envolvam interesses relevantes (art. 178 do Código de Processo Civil).

Assim, na condição de parte, o Ministério Público pode propor ação civil pública para obtenção de ressarcimento de patrimônio público ou para a tutela de direitos difusos (como a proteção do meio ambiente), ou de direitos individuais homogêneos (como a proteção de grupo de consumidores lesados em razão de falha na prestação de serviço de fornecimento de água). Já quando atua como custos juris, em sendo proposta ação civil pública por uma associação ou por um Município, ou ainda em uma ação popular destinada a anular atos lesivos ao erário, o Ministério Público sempre intervirá como fiscal da ordem jurídica.

É indiscutível que o ordenamento jurídico pátrio concede ao Ministério Público capacidade para realizar atos negociais com a finalidade de obter a solução da controvérsia, 
sempre voltados ao restabelecimento da legalidade, na defesa do ordenamento jurídico. O maior exemplo disso é o termo de ajustamento de conduta que permite ao Parquet sanar ilegalidades extrajudicialmente, solucionando o conflito mediante negociação. Também não se discute a possibilidade de se firmar termo de ajustamento de conduta durante o trâmite processual, possibilitando que este acordo promova uma solução mais célere da controvérsia, evitando, inclusive, que a demanda se arraste em decorrência de propositura de recursos.

Como o Ministério Público tem a sua atuação pautada na promoção do interesse público primário, ou seja, o bem-estar social pela garantia do regime democrático e da ordem jurídica, o mesmo raciocínio desenvolvido no tópico anterior referente à Fazenda Pública aplica-se ao Ministério Público quanto à inexistência de impedimento à realização de convenção processual, desde que seja utilizada de forma impessoal, moral, transparente, com o intuito de se alcançar maior eficiência na tutela dos direitos difusos, coletivos e individuais homogêneos.

Como a atuação do Parquet é sui generis, visto que ora milita como parte, ora como custos juris, é preciso abordar se é admissível a realização de negociação processual em ambas as formas de intervenção ministerial.

$A b$ initio, é pertinente destacar que o legislador pátrio atribuiu tal importância à proteção dos direitos difusos e coletivos socialmente relevantes que previu a possibilidade de assunção do polo ativo da demanda pelo Parquet quando houver desistência infundada ou abandono da ação civil pública ou da ação popular pelo seu autor ( $\operatorname{art.} 5^{\circ}, \S 3^{\circ}$, da Lei ${ }^{\circ}$ 7.347/85 e art. $9^{\circ}$ da Lei $n^{\circ}$ 4.717/65). Ou seja, mesmo atuando como custos juris, o Ministério Público poderá convolar-se em autor, se houver abandono ou desistência por parte de um dos colegitimados.

Em razão dessa forma peculiar de atuação no processo, Maria Sylvia Zanela Di Pietro $^{20}$ ressalta que de todas as instituições jurídicas, o Ministério Público, atualmente, é a

\footnotetext{
20 DI PIETRO, Maria Sylvia Zanella. O Ministério Público como instituição essencial à justiça. In: RIBEIRO, Carlos Vinícius Alves (org.). Ministério Público: reflexões sobre princípios e funções institucionais. São Paulo: Atlas, 2010, p. 08-12.
} 
que detém o maior rol de atribuições e responsabilidades, exigindo-se que haja um equilíbrio entre a parcialidade do advogado que atua na defesa do interesse público e a imparcialidade de quem foi incumbido pelo Constituinte de promover a defesa da ordem jurídica, do regime democrático e dos interesses sociais indisponíveis.

Nesse diapasão, a atuação do agente ministerial, seja quando atue como custos juris ou quando se apresente como parte terá que primar, sempre, pela proteção do interesse público primário, competindo-lhe, inclusive requerer a improcedência da própria demanda por ele proposta quando a instrução processual demonstrar serem insubsistentes as provas para demonstrar o fato narrado na exordial.

Isso significa que, em qualquer hipótese, como parte ou custos juris, o Ministério Público deverá zelar pela tutela do ordenamento jurídico, a qual poderá ser feita de forma bem mais eficaz por meio da celebração de uma convenção processual que garanta maior celeridade na produção de provas ou na produção dos efeitos da coisa julgada.

Exemplificando-se, em uma ação de improbidade administrativa quando proposta pelo Ministério Público, por exemplo, este poderá ou não apresentar rol de testemunhas. Ora se o Parquet pode até mesmo se abster de requerer a oitiva de testemunhas, por qual razão não poderia, no curso do trâmite processual, ou até mesmo em um termo de ajustamento de conduta firmado antes da propositura da demanda, firmar convenção processual que definisse exclusividade de produção de prova documental?

Pensando-se em uma situação em que a atuação se dê como custos juris, também não se vislumbra óbice a que seja firmada convenção processual pelo Ministério Público desde que seu objeto esteja dentro do âmbito de suas faculdades processuais, desde que se trate de estratégia destinada a tutelar mais eficazmente o interesse público. Isso significa que o Ministério Público, atuando como custos juris, não poderá firmar compromisso pela parte que não tenha anuído à convenção, estando a negociação processual restrita aos seus signatários. 
A maior parcela dos juristas entende não ser possível a realização de negócio processual pelo Ministério Público quando atua como custos juris, sob o argumento de que o art. 190 do Código de Processo Civil cita expressamente palavra "partes"21.

Contudo, não se pode fazer uma interpretação restritiva da norma. A legislação deve ser interpretada em conformidade com os princípios que regem nosso ordenamento jurídico, especialmente os consagrados na Constituição Federal e, conforme já mencionado anteriormente neste trabalho, a convenção processual consagrou o princípio da autonomia da vontade que é a verdadeira decorrência do direito constitucional à liberdade, tendo sido destacado no novo Código de Processo Civil o dever de colaboração com o processo para todos os atores que estiverem nele envolvidos e não apenas às partes ${ }^{22}$.

Essa mudança de paradigmas introduzida pela Lei $n^{\circ} 13.105 / 2015$ foi desenvolvida com o intuito de se otimizar a efetivação da justiça, verificando-se que a legislação processual civil vigente foi concebida com o objetivo de promover a realização da justiça, mediante a busca de meios mais eficazes de solução dos conflitos, entre os quais ampliação da conciliação e mediação, bem como o incremento da possibilidade de se realizar negócios processuais para a obtenção de uma solução mais adequada à demanda.

Nesse diapasão, se compete ao Ministério Público intervir ora como parte, ora como custos juris, tendo a legitimidade de sua atuação pautada no interesse público, não se pode impedir que este realize uma convenção processual que demonstre ter por finalidade a obtenção de uma solução mais adequada à resolução do conflito, ainda que, na hipótese, esteja atuando como fiscal da ordem jurídica.

Não se pode olvidar que essa nova sistemática decorreu da busca para se construir um complexo de normas processuais que se mostrasse mais adequado à solução das controvérsias postas em juízo, justamente porque a antiga sistemática que tinha como pilar a autonomia do direito processual se mostrou ineficiente para a promoção da finalidade

\footnotetext{
${ }^{21}$ Art. 190. Versando o processo sobre direitos que admitam autocomposição, é lícito às partes plenamente capazes estipular mudanças no procedimento para ajustá-lo às especificidades da causa e convencionar sobre os seus ônus, poderes, faculdades e deveres processuais, antes ou durante o processo (sem destaque no original).

${ }^{22}$ Vide artigos. $5^{\circ}$ e $6^{\circ}$ do CPC/2015 e ainda art. 401 que prevê o dever de terceiro exibir documento que se ache em seu poder.
} 
almejada na demanda que é a paz social, por meio da obtenção da justiça. Por isso, o declínio do processualismo em si mesmo está diretamente relacionado à crescente preocupação com a efetividade da tutela jurisdicional, ou seja, com a concreta realização do ideal de justiça ${ }^{23}$.

Como já se discorreu anteriormente neste trabalho, o direito processual, atualmente, está na fase denominada neoprocessualista, em que se busca alcançar por meio do processo o ideal de justiça preconizado na Constituição Federal. Uma das exteriorizações disso é justamente as decisões já proferidas pelo Supremo Tribunal Federal e pelo Superior Tribunal de Justiça no sentido de se relativizar a coisa julgada quando a decisão judicial se mostra inconstitucional ${ }^{24}$, consagrando o entendimento de que não produz coisa material as decisões que se encontrarem dissociadas dos princípios e fundamentos da Carta Constitucional ${ }^{25}$.

Baseado nessas premissas, atualmente, entende-se que o princípio do devido processo legal não é a mera concatenação de atos especificados na legislação, o referido princípio se concretiza quando a tutela jurisdicional é prestada de forma justa e efetiva, atendendo-se ao comando constitucional da razoável duração do processo $^{26}$.

Como bem se percebe, como as normas processuais devem ser interpretadas à luz dos princípios e valores consagrados em nosso ordenamento jurídico, fazendo com que o processo civil seja entendido como meio de se alcançar a solução mais adequada ao conflito. Inexiste razão, portanto, para que se dê interpretação restritiva ao art. 190 do Código de Processo Civil, devendo o conceito de parte ser entendido como todos aqueles que estiverem atuando no processo, sendo possível ao Ministério Público firmar convenção processual com o intuito de obter a solução da lide que mais se adéque ao interesse público, ainda que atue como custos juris.

\footnotetext{
${ }^{23}$ MADUREIRA, Claudio. O CPC-2015 e a relativização da coisa julgada: uma proposta de aplicação prática da teoria. Rio de Janeiro: Lumen Juris, 2016, 1.ed, p. 57.

${ }^{24}$ Como exemplo, o julgamento do REsp 240.712/SP que suspendeu pagamento determinado em sentença de mérito com trânsito em julgado porque se mostrou dissociado dos princípios constitucionais.

${ }^{25}$ Para maior aprofundamento desta matéria vide MADUREIRA, Claudio. Op. Cit.

${ }^{26}$ WAMBIER, Luiz Rodrigues. O modelo processual cooperativo e a flexibilização procedimental. Revista Eletrônica de Direito Processual. Rio de Janeiro: ano 11, v. 18, n.3, set a dez 2017, p. 247-248. Disponível em: <https://www.e-publicacoes.uerj.br/index.php/redp/article/view/31696>. Acesso em: janeiro de 2018.
} 
Justamente para atender a esse espírito de solução adequada de conflitos, preconizado pelo legislador, denominado pela doutrina de justiça multiportas, o próprio CNMP editou a Resolução $n^{\circ}$ 118/2014 que dispõe sobre a implementação e adoção pelo Ministério Público de mecanismos de autocomposição, negociação, mediação, conciliação, práticas restaurativas e convenções processuais.

Os artigos 15 a 17 da referida Resolução tratam, justamente, da possibilidade de se firmar convenções processuais pelo Parquet, podendo até mesmo ser documentadas em termo de ajustamento de conduta, devendo-se ressaltar que a referida norma não restringe a utilização desse instrumento processual apenas às hipóteses em que o Ministério Público atue como parte.

Conforme esclarece Luciano Badini ${ }^{27}$, a partir de agora os termos de ajustamento de conduta podem ser revistos e ampliados, posto que não se restringirão mais à forma, prazo e local de cumprimento, podendo englobar os negócios processuais, com fundamento no art. 190 do Código de Processo Civil e art. 16 da Resolução 118/2014 do CNMP.

Antonio do Passo Cabral e Leonardo Carneiro da Cunha ${ }^{28}$ mencionam que as convenções processuais fazem parte do sistema de collaborative law instituído pelo novo Código de Processo que, ao lado da negociação, mediação e conciliação, podem ser eficazmente utilizadas pelo Ministério Público para solução das controvérsias de que participe.

\section{Legitimidade recursal do Ministério Público (poder-dever ou faculdade} processual) e a possibilidade de realização de convenção processual em matéria recursal

\footnotetext{
${ }^{27}$ BADINI, Luciano. Reflexões sobre a negociação e mediação para o Ministério Público. In: ZANETI JUNIOR, Hermes; CABRAL, Trícia Navarro Xavier (coords.). Justiça Multiportas: mediação, conciliação, arbitragem e outros meios de solução adequada para conflitos. Salvador: Juspodivm, 2016, p. 234.

28 CABRAL, Antonio do Passo; CUNHA, Leonardo Carneiro da. Negociação direta ou resolução colaboração de disputas (collaborative law). In: ZANETI JÚNIOR, Hermes; CABRAL, Trícia Navarro Xavier (coords.). Justiça Multiportas: mediação, conciliação, arbitragem e outros meios de solução adequada para conflitos. Salvador: Juspodivm, 2016, p. 723.
} 
É indiscutível que o Ministério Público pode interpor recurso quando atua como parte ou como custos juris $^{29}$, pois a lei processual preconiza a legitimidade extraordinária, em alguns casos, para a propositura de recursos como, por exemplo, ao Parquet enquanto fiscal da ordem jurídica e ao terceiro prejudicado.

Há quem defenda, inclusive, a exemplo de Júlia Lipiani e Marília Siqueira ${ }^{30}$, ao interpretar o art. 18 e 190 do Código de Processo Civil, a possibilidade de ser conferida, por meio de convenção processual, legitimidade recursal a terceiro para interpor recurso no lugar da parte, que seria uma forma de legitimação extraordinária recursal, caracterizada por uma intervenção de terceiro atípica.

É necessário explorar, contudo, se o Parquet é obrigado a propor recurso nos processos em que atue, de acordo com a situação fática posta em juízo. Sobre esse tema, consoante bem esclarece a doutrina, um dos princípios que regem os recursos é a voluntariedade. Como bem ressalta Humberto Theodoro Júnior, o direito de recorrer encontra-se inserido no próprio caráter dispositivo do direito de ação ${ }^{31}$.

De forma semelhante, Júlia Lipiani e Marília Siqueira ${ }^{32}$ discorrem que recurso é remédio voluntário, não possuindo compulsoriedade, sendo o direito de recorrer, portanto, potestativo, não havendo óbice à pactuação que tenha por objeto renúncia a recurso, para estabelecer, por exemplo, supressão da segunda ou terceira instância. Ressalte-se que a ideia de contratualização do processo já era prevista em outros ordenamentos jurídicos, tal como o francês ${ }^{33}$ e o português, em cujas legislações há previsão de pacto de renúncia a recurso ou acordo de instância única.

Assim, considerando que, embora o Ministério Público atue em matéria de direitos indisponíveis, não está o Parquet obrigado a propor recurso, face à incidência do princípio

\footnotetext{
${ }^{29}$ Art. 996 do Código de Processo Civil

${ }^{30}$ LIPIANI, Júlia; SIQUEIRA, Marília. Negócios jurídicos processuais sobre a fase recursal. In: CABRAL, Antonio do Passo; NOGUEIRA Pedro Henrique (coords.). Negócios processuais. Salvador: Juspodvm, 2015, v.1, p. 461-462.

${ }^{31}$ THEODORO JUNIOR, Humberto. Curso de direito processual civil. Rio de Janeiro: Forense, $2017,50$. ed., v. 3, p. 974.

${ }^{32}$ LIPIANI, Júlia; SIQUEIRA, Marília. Op. Cit. p. 465-467.

${ }^{33}$ Para maior aprofundamento vide CADIET, Loic. La qualification juridique des accords processuels. In: CABRAL, Antonio do Passo; NOGUEIRA, Pedro Henrique (coords.). Negócios processuais. Salvador: 2015, p. 93-103.
} 
da voluntariedade, entretanto poderá optar em fazê-lo, seja como parte ou como físcal da ordem jurídica. Partindo-se dessa premissa, de que não existe obrigatoriedade de ser proposto recurso pelo Ministério Público, ainda que o direito por ele defendido se sagre vencido, como por exemplo, numa ação de ressarcimento ao erário, também não se vislumbra razão para se entender que não lhe é permitido renunciar ou desistir de um recurso em processos cíveis, por meio de uma convenção processual.

É totalmente ultrapassado o entendimento de que, somente porque o Ministério Público atua na defesa do interesse público, não se poderia considerar que estaria atendido esse interesse por ele tutelado ao renunciar à sua faculdade recursal, especialmente agora que o atual Código de Processo Civil conferiu especial relevância aos precedentes, tornando-os vinculantes para as decisões judiciais.

Deve-se ressaltar que, com a sistemática da força vinculante dos precedentes, instituído pelo art. 927 e 489, $\S 1^{\circ}$, ambos do Código de Processo Civil existe maior razão para que o Ministério Público avalie, em cada caso, se deve propor recurso ou se é melhor renunciar a essa faculdade, a fim de que seja possível levar às Cortes Superiores os casos que tenham maior possibilidade de tornar vencedora a tese defendida pelo Parquet.

Não se pode olvidar que já há quem defenda que a força vinculante das decisões proferidas pelas Cortes Superiores não se restringe às hipóteses descritas no art. 927 do Código de Processo Civil, tal como Luiz Guilherme Marinoni ${ }^{34}$ que defende que a ratio decidendi de qualquer das decisões proferidas em recurso extraordinário ou especial, ainda que não sejam repetitivas devem vincular os juízes e tribunais, pois, para o jurista, a palavra final sobre a interpretação da Constituição e da Lei Federal são do STF e do STJ, respectivamente, ainda que não se trate de recursos repetitivos, ao interpretar o $489, \S 1^{\circ}$ :

Assim, considerando a necessidade de se ponderar os casos mais relevantes que devem ser levados à apreciação das cortes superiores, aliado ao princípio da voluntariedade que disciplina os recursos, conclui-se que não se deve restringir a possibilidade de o Ministério Público realizar negócio processual em matéria recursal, obviamente, que diga respeito à sua faculdade processual de recorrer, devendo ser admitido que possa renunciar 34 MARINONI, Luiz Guilherme. O julgamento nas cortes supremas: precedentes e decisão do recurso
diante do novo CPC. São Paulo: Revista dos Tribunais, 2015, p. 25 . 
ou desistir ainda que sua atuação se dê como custos juris, ressaltando-se que tal convenção processual somente atingiria os seus signatários.

\section{Conclusão}

O ordenamento jurídico deve ser interpretado com unidade e coerência. Por isso, se a legislação processual consagrou o princípio da autonomia da vontade como sendo um dos pilares do direito à liberdade preconizado na Constituição Federal, bem como previu, em diversos dispositivos o dever de cooperação das partes e de terceiros com o processo, com o objetivo de se alcançar a solução adequada do conflito, não se pode conferir uma interpretação restritiva ao art. 190 do Código de Processo Civil.

O Ministério Público quando atua no processo, seja como parte ou como fiscal da ordem jurídica, sempre objetiva alcançar bem comum pela promoção do interesse público primário, do qual faz parte a adequada solução do conflito posto em juízo, verificando-se que os negócios processuais podem ser uma forma de se obter maior efetividade e celeridade na resolução dos conflitos com a participação efetiva dos atores envolvidos no processo.

Em sendo a convenção processual utilizada de forma impessoal, legal, moral e transparente, com o intuito de se alcançar maior eficiência na tutela dos direitos difusos, coletivos e individuais indisponíveis, inexiste razão para se restringir a sua utilização pelo Ministério Público apenas quando atue como parte, pois tal interpretação dissocia-se totalmente de finalidade de obtenção de solução adequada da controvérsia, introduzida na nova sistemática do Código de Processo Civil, sendo, portanto, possível que o Ministério Público firme acordo processual de instância única, ainda que esteja agindo como custos juris.

\section{REFERÊNCIAS}

BADINI, Luciano. Reflexões sobre a negociação e mediação para o Ministério Público. In: ZANETI JUNIOR, Hermes; CABRAL, Trícia Navarro Xavier (coords.). Justiça 
Multiportas: mediação, conciliação, arbitragem e outros meios de solução adequada para conflitos. Salvador: Juspodivm, 2016, p. 225-235.

CABRAL, Antonio do Passo; CUNHA, Leonardo Carneiro da. Negociação direta ou resolução colaboração de disputas (collaborative law). In: ZANETI JÚNIOR, Hermes; CABRAL, Trícia Navarro Xavier (coords.). Justiça Multiportas: mediação, conciliação, arbitragem e outros meios de solução adequada para conflitos. Salvador: Juspodivm, 2016, p. 709-726.

CADIET, Loic. La qualification juridique des accords processuels. In: CABRAL, Antonio do Passo; NOGUEIRA, Pedro Henrique. (Coords.). Negócios processuais. Salvador: Juspodivm, 2015, v.1, p. 93-103.

CIANCI, Mirna; MEGNA, Bruno Lopes. Fazenda Pública e Negócios Jurídicos Processuais no novo CPC: Pontos de partida para o estudo. In: CABRAL, Antonio; NOGUEIRA, Pedro Henrique Pedrosa (Coords.). Negócios processuais. Salvador: Juspodivm, 2015, v.1.

CUNHA, Leonardo Carneiro da. A Fazenda Pública em juízo. Rio de Janeiro: Forense, 2017, 14. ed.

- Negócios jurídicos processuais no processo civil brasileiro. In: CABRAL, Antonio do Passo; NOGUEIRA, Pedro Henrique. (Coords.). Negócios processuais. Salvador: Juspodivm, 2015, v.1, p. 27-62.

DIDIER JR., Fredie. Princípio do respeito ao autorregramento da vontade no Processo Civil. In: CABRAL, Antonio; NOGUEIRA, Pedro Henrique Pedrosa (Coords.). Negócios processuais. Salvador: Juspodivm, 2015, v.1, p. 19-21.

.; BOMFIM, Daniela Santos. A colaboração premiada como negócio jurídico processual atípico nas demandas de improbidade administrativa $A \& C$. Revista de Direito Administrativo \& Constitucional. Belo Horizonte, ano 17, n. 67, p. 105-120, jan./mar. 2017. DOI: 10.21056/aec.v17i67.475. Disponível em <https://www.academia.edu/32483221/A_colabora\%C3\%A7\%C3\%A3o_premiada_c omo_neg\%C3\%B3cio_processual_at\%C3\%ADpico_no_processo_da_improbidade_ administrativa>. Acesso em: fevereiro de 2018. 
DI PIETRO, Maria Sylvia Zanella. O Ministério Público como instituição essencial à justiça. In: RIBEIRO, Carlos Vinícius Alves (org.). Ministério Público: reflexões sobre princípios e funções institucionais. São Paulo: Atlas, 2010, p. 03-12.

DONIZETE, Elpídio. Curso didático de direito processual civil. São Paulo: Atlas, 2017, 20. ed.

. Novo código de processo civil comentado (Lei $n^{o} 13.105$, de 16 de março de 2015): análise comparativa entre o novo CPC e o CPC/73. São Paulo: Atlas, 2015.

FURLAN, Simone. A audiência de saneamento compartilhado do art. 357, $\S 3^{\circ}$, do cpc/2015 e os princípios da cooperação e efetividade. Revista Eletrônica de Direito Processual - REDP, Rio de Janeiro: 2017, Ano 11, volume 18, número 3, set./dez. 2017. Disponível em: <https://www.epublicacoes.uerj.br/index.php/redp/article/view/31700>. Acesso em: 04 de fevereiro de 2018.

GOMES, Raphael Noleto Auad de. Da (in)aplicabilidade da cláusula geral de negociação processual no âmbito da fazenda pública em juízo. Revista de Direito da Procuradoria-Geral do Estado de Goiás - RPGEGO, Belo Horizonte, ano 29, n. 31, jan/dez., 2016, $\quad$ p. $19 . \quad$ Disponível em: $<$ http://www.bidforum.com.br/bidBiblioteca_pre_periodico_ap.aspx?tp=1\&p=1550 \&abrev=REV>. Acesso em: fevereiro de 2018.

LIPIANI, Júlia; SIQUEIRA, Marília. Negócios jurídicos processuais sobre a fase recursal. In: CABRAL, Antonio do Passo; NOGUEIRA Pedro Henrique (coords.). Negócios processuais. Salvador: Juspodvm, 2015, v.1, p. 445-479.

MADUREIRA, Claudio. O CPC-2015 e a relativização da coisa julgada: uma proposta de aplicação prática da teoria. Rio de Janeiro: Lumen Juris, 2016, 1.ed.

MARINONI, Luiz Guilherme. O julgamento nas cortes supremas: precedentes e decisão do recurso diante do novo CPC. São Paulo: Revista dos Tribunais, 2015.

MAZZEI, Rodrigo; CHAGAS, Barbara Seccato Ruis. Os negócios jurídicos processuais e a arbitragem. In: CABRAL, Antonio; NOGUEIRA, Pedro Henrique Pedrosa (Coords.). Negócios processuais. Salvador: Juspodivm, 2015, v.1, p. 521-539. 
MONTENEGRO FILHO, Misael. Novo código de processo: modificações substanciais. São Paulo: Atlas, 2015.

THEODORO JUNIOR, Humberto. Curso de direito processual civil. Rio de Janeiro: Forense, 2017, 50. ed., v. 3.

WAMBIER, Luiz Rodrigues. O modelo processual cooperativo e a flexibilização procedimental. Revista Eletrônica de Direito Processual. Rio de Janeiro: ano 11, v. 18, n.3, set a dez 2017, p. 238-255. Disponível em: <https://www.epublicacoes.uerj.br/index.php/redp/article/view/31696>. Acesso em: janeiro de 2018. .; TALAMINI, Eduardo. Curso avançado de processo civil: teoria geral do processo. São Paulo: Revista dos Tribunais, 2016, 16. ed., v.1. 